В. М. Ждан, В. М. Дворник, С. М. Білаш, О. М. Бєляєва Вищий державний навчальний заклад Украйни

“Українська медична стоматологічна академія"

\title{
РЕЗУЛЬТАТИ САМОАНАЛІЗУ ОРГАНІЗАЦІЙНО-ПРАВОВОГО, КАДРОВОГО І НАВЧАЛЬНО-МЕТОДИЧНОГО ЗАБЕЗПЕЧЕННЯ ПРОЦЕСУ ПІДГОТОВКИ ФАХІВЦІВ ГАЛУЗІ ЗНАНЬ 22 “ОХОРОНА ЗДОРОВ’Я” У ВДНЗУ “УМСА” ЗА 2017 РІК
}

\author{
V. M. Zhdan, V. M. Dvornyk, S. M. Bilash, O. M. Bieliaieva \\ Higher State Educational Establishment of Ukraine \\ "Ukrainian Medical Stomatological Academy"

THE RESULTS OF SELF-ANALYSIS OF ORGANIZATIONAL, LAW,
PERSONNEL, EDUCATIONAL AND METHODICAL FRAMEWORK IN
THE PROCESS OF TRAINING SPECIALISTS OF THE BRANCH OF
KNOWLEDGE 22 “HEALTHCARE” AT THE UKRAINIAN MEDICAL
STOMATOLOGICAL ACADEMY OVER THE PERIOD OF 2017

Мета роботи - провести самоаналіз організаційно-правового, кадрового та навчально-методичного забезпечення процесу підготовки фахівців галузі знань 22 “Охорона здоров”я” у ВДНЗУ “УМСА” у 2017 році.

Основна частина. Узагальнено результати самоаналізу організаційно-правового, кадрового і навчально-методичного забезпечення процесу підготовки фахівців галузі знань 22 “Охорона здоров'я” у ВДНЗУ “УМСА” за 2017 рік. Продемонстровано позитивні результати освітньої діяльності академії протягом вказаного періоду. Визначено першочергові завдання, спрямовані на покращення кадрового і навчально-методичного забезпечення освітнього процесу та, як наслідок, конкурентоспроможності академії.

Висновок. Проведений самоаналіз організаційно-правового, кадрового і навчально-методичного забезпечення процесу підготовки фахівців галузі знань 22 “Охорона здоров'я” у ВДНЗУ “УМСА” за 2017 рік засвідчив, що це забезпечення відповідає чинному законодавству України, свідчить про ефективний менеджмент керівництва та ефективність управлінських рішень.

Ключові слова: освітня діяльність; організаційно-правове, навчально-методичне, кадрове забезпечення; підвищення кваліфікації.

The aim of the work - to carry out an in-depth review of the organizational-legal, personnel and educational and methodological support for the process of training specialists in the field of knowledge 22 "Health" at the Ukrainian Medical Stomatological Academy in 2017.

The main body. The article summarizes the results of self-analysis of organizational, law, personnel, educational and methodical framework in the process of training specialists in the field of knowledge 22 "Healthcare" at the Ukrainian Medical Stomatological Academy over the period of 2017. The Academy's achievements during the above-stated period have been represented. The conclusions delineate the priority tasks, aimed at enhancing the personnel, educational and methodical framework and, as a result, the competitive ability of the Academy.

Conclusion. Conducted self-examination of organizational, legal, personnel and teaching methods for the training of specialists in the field of knowledge 22 "Health" at the Ukrainian Medical Stomatological Academy for 2017 showed that this provision is in accordance with the current legislation of Ukraine, testifies to the effective management of direction and the effectiveness of management decisions.

Key words: educational activities; organizational-law; educational and methodical,staffing framework; advanced training.

Вступ. На початку третього тисячоліття Україна впритул підійшла до трансформаційної межі, коли пульс змін відчувається, як ніколи раніше. Відбувається кардинальна зміна вектора розвитку країни, соціокультурних очікувань, modus'y vivendi та

( ) В. М. Ждан, В. М. Дворник, С. М. Білаш, О. М. Бєляєва modus'y cogitandi, що знаходить своє втілення в організації, функціонуванні й розвитку всіх сфер життя суспільства [5].

Проте світовий і вітчизняний досвід переконливо доводить, що жодні докорінні зміни й інноваційні процеси не принесуть бажаного результату 
без інноваційно мислячого та інноваційно діючого фахівця нового типу, тому цілком закономірно, що системні зміни у вітчизняній медицині й медичній освіті потребують нової генерації якісно та різнобічно підготовлених лікарів і медичних сестер, що покладає особливу відповідальність на вітчизняну вищу медичну школу, яка має до цього достатньо серйозний потенціал [7].

У даному контексті варто наголосити, що потреба в комплексних змінах практичної системи охорони здоров'я і підготовки медичних кадрів - це далеко не лише українська проблема, оскільки за умов глобалізації, яка породжує жорстку конкуренцію між постачальниками освітніх послуг, практично всі європейські країни мають спільні проблеми в галузі кадрових ресурсів: дефіцит, пов'язаний 3 особливостями підготовки медичних кадрів у різних країнах; обмежена кількість компетентних і висококваліфікованих медичних працівників різної ланки, а також тих, чия компетентність цілком відповідає локальним потребам; більшість країн відчуває гостру нестачу фахівців, які володіють найважливішими навичками, необхідними для охорони здоров'я населення; більшість європейських країн стикається з проблемою незбалансованого розподілу кадрових ресурсів, які концентруються в містах (особливо мегаполісах) і відсутні на периферії, особливо в сільській місцевості; незадоволення медичних працівників, спричинене несприятливим професійним середовищем: відзначаються відсутність підтримки з боку керівного персоналу, недостатнє соціальне визнання, слабке кар'єрне зростання, низька заробітна плата і нестача мотивації; зростання мобільності або так звана “незапланована міграція” і різне ставлення до цього явища: “країнидонори” висловлюють усе більшу стурбованість відтоком кваліфікованих медичних кадрів, тоді як “країни-реципієнти” розглядають цей процес як один із можливих шляхів “розв’язання” вказаної проблеми; обмежені можливості в регулюванні й управлінні, неналежний рівень моніторингу і брак доступної інформації щодо якості освіти і підготовки медичних кадрів, їх готовності до практичної діяльності еtс. [6, 12].

Якщо окреслені вище об'єктивні та суб'єктивні фактори мають глобальну тенденцію і системний характер, а тому довгоочікувані зміни не можуть відбутися одномоментно, існує низка питань, вирішення яких безпосередньо залежить від ефективного менеджменту керівників ВМ(Ф)НЗ і роботи колективів даної групи закладів вищої освіти, - це питання організаційно-правового, кадрового та навчально-методичного забезпечення процесу підготовки фахівців галузі знань 22 “Охорона здоров'я”.

Мета роботи - провести самоаналіз організаційно-правового, кадрового та навчально-методичного забезпечення процесу підготовки фахівців галузі знань 22 “Охорона здоров'я” у ВДНЗУ “УМСА” за 2017 рік

Основна частина. Освітня діяльність у ВДНЗУ “УМСА” провадиться відповідно до чинних правових актів: законів України (“Про освіту”, “Про вищу освіту”, "Про наукову і науково-технічну діяльність”, “Авторське право і суміжні права”), Кодексу законів України про працю, постанов і рішень Верховної Ради, указів та розпоряджень Президента України, постанов і розпоряджень Кабінету Мiністрів України, нормативно-правових документів MO3 України та МОН України, наказів Департаменту охорони здоров'я і Департаменту освіти і науки Полтавської обласної державної адміністрації, Статуту академії, локальних нормативно-правових актів (інструкцій та положень), які регламентують діяльність структурних підрозділів академії.

На виконання ст. 47 розділу IX “Організація освітнього процесу” Закону України “Про вищу освіту” [2] і Постанови Кабінету Міністрів України від 30.12.2015 року № 1187 “Про затвердження Ліцензійних умов провадження освітньої діяльності закладів освіти” [10] науково-методичне та навчально-методичне забезпечення освітнього процесу відповідає п. 14 “Технологічні вимоги щодо забезпечення провадження освітньої діяльності у сфері вищої освіти” розділу “Вимоги щодо провадження освітньої діяльності у сфері вищої освіти” і здійснюється відповідно до Положення про організацію освітнього процесу у ВДНЗУ “УМСА" (остання редакція ухвалена рішенням ученої ради академії від 30.08.2017 року (протокол № 1), затверджена наказом ректора академії від 30.08.2017 року № 274), яке регламентує вимоги щодо наявності, форми та змісту документації, що стосується нормативно-правової бази організації освітнього процесу, планування змісту навчання, планування роботи кафедри, обліку реалізації навчального процесу, власне методичної документації.

3 огляду на те, що одне з першочергових завдань з удосконалення навчально-методичного забезпечення навчального процесу полягає в організації його належної підготовки науково-педагогічними 
працівниками кафедр і суворому контролі з боку адміністрації за постійним оновленням цього забезпечення [8], в академії приділяють пильну увагу вказаному питанню. Викладання всіх дисциплін забезпечене методичним супроводом у вигляді: тезових (або повнотекстових) методичних розробок лекцій; методичних рекомендацій для викладачів; методичних вказівок для організації аудиторної (позаудиторної) самостійної роботи студентів під час підготовки до практичного (семінарського) заняття та на занятті (трьома мовами); переліку теоретичних питань до ПМК; переліку практичних навичок $з$ дисципліни; щорічно поновлюваного списку літератури, рекомендованої при вивченні кожної дисципліни (трьома мовами); матеріалів для контролю (поточного, проміжного, підсумкового) знань, умінь, навичок студентів (трьома мовами), що містять, залежно від виду контролю і дисципліни, тести різного виду (закриті та відкриті) і різних рівнів складності; тести з банку ліцензійних іспитів (для дисциплін, питання яких входять до бази ліцензійних інтегрованих іспитів); ситуаційні задачі; затверджені відповідною цикловою комісією завдання (білети) для складання ПМК та іспитів.

Для забезпечення всіх рівнів міжпредметної інтеграції розроблено наскрізні програми практичних навичок з конкретної дисципліни з урахуванням знань, умінь і навичок із суміжних дисциплін. Окремо до кожної дисципліни розроблено довідники для студентів (трьома мовами), в яких подається вичерпна для особи, яка навчається, інформація про дисципліну: структура дисципліни; перелік компетентностей (загальних, предметних); опис модулів навчальної дисципліни; конвертація традиційної оцінки в бали та критерії оцінювання навчальної діяльності студента; рекомендована література.

На виконання ст. 51 "Практична підготовка осіб, які навчаються у вищих навчальних закладах” розділу IX “Організація освітнього процесу” Закону України “Про вищу освіту” [2] та згідно з наказами МО3 України від 05.06.1997 року № 174 “Положення про клінічний заклад” і від 14.09.1998 року № 273, "Про надання статусу клінічних закладів лікувально-профілактичним закладам охорони здоров’я Автономної Республіки Крим, Дніпропетровської, Одеської, Вінницької, Харківської, Київської, Донецької, Запорізької, Тернопільської, Полтавської, Львівської, Волинської, Чернівецької, Херсонської областей та м. Києва”, студенти академії проходять виробничу практику у відповідних закладах міського й обласного підпорядкування, що отримали статус клінічних. Науково-педагогічні працівники клінічних кафедр, розміщених на цих базах, розробили методичні рекомендації з організації і проведення виробничої практики, а також перелік практичних навичок, якими повинен оволодіти або які повинен удосконалити студент під час проходження практики. Обов'язковим елементом методичного супроводу на кафедрах, які забезпечують професійну і практичну підготовку, є Наскрізна програма підготовки студентів медичних факультетів вищих медичних навчальних закладів IV рівня акредитації та лікарів-інтернів для оволодіння практичними навичками та методиками, необхідними для роботи на посадах лікарів за спеціальністю “Загальна практика - сімейна медицина”.

У фокусі уваги адміністрації академії перебувають питання належної організації профорієнтаційної роботи та роботи приймальної комісії. Це підтверджується тим фактом, що під час роботи Державної інспекції навчальних закладів України, яка працювала в академії з 17 до 23 вересня 2017 року, не було виявлено жодних порушень в організації та проведенні конкурсного зарахування на I курс у 2017 році за результатами 3НО і вступних випробувань.

Слід зазначити, що в руслі сучасних вимог щодо реформування системи вищої медичної освіти в Україні [13] в академії розпочато роботу в напрямку підвищення порога мінімального прохідного бала для зарахування на медичні (фармацевтичні) спеціальності. Так, у 2017 році серед ВМ(Ф)НЗ, підпорядкованих МОЗ України, академія посіла друге місце за кількістю вступників із балами менше 150 , яких було рекомендовано до зарахування на навчання за спеціальністю 222 “Медицина”, що представлено на рисунку 1.

Підтвердженням того, що організаційно-правове, кадрове, навчально-методичне забезпечення освітнього процесу підготовки фахівців для системи охорони здоров'я відповідає сучасним вимогам, слугує той факт, що 20 жовтня 2017 року академія вкотре успішно пройшла наглядовий аудит щодо відповідності міжнародним вимогам освітніх послуг, пов'язаних із одержанням вищої освіти на рівні кваліфікаційних вимог до молодшого спеціаліста, спеціаліста, магістра, у т. ч. для іноземних громадян, а також підготовки науково-педагогічних кадрів і отримала сертифікат системи менеджменту якості (стандарт ДСТУ ISO 9001:2015). 
Д3 “Луганський державний медичний університет”

Львівський національний медичний університет імені Данила Галицького

Донецький національний медичний університет

ДВНЗ “Тернопільський державний медичний університет імені І. Я. Горбачевського МОЗ України"

ДВНЗ “Івано-Франківський національний медичний університет”

Харківський національний медичний університет

Вінницький національний медичний університет ім. М. І. Пирогова

ВДНЗУ “Буковинський медичний університет”

ДЗ “Дніпропетровська медична академія”

Національний медичний університет ім. О. О. Богомольця

Одеський національний медичний університет

ВДНЗУ “Українська медична стоматологічна академія”

Запорізький державний медичний університет

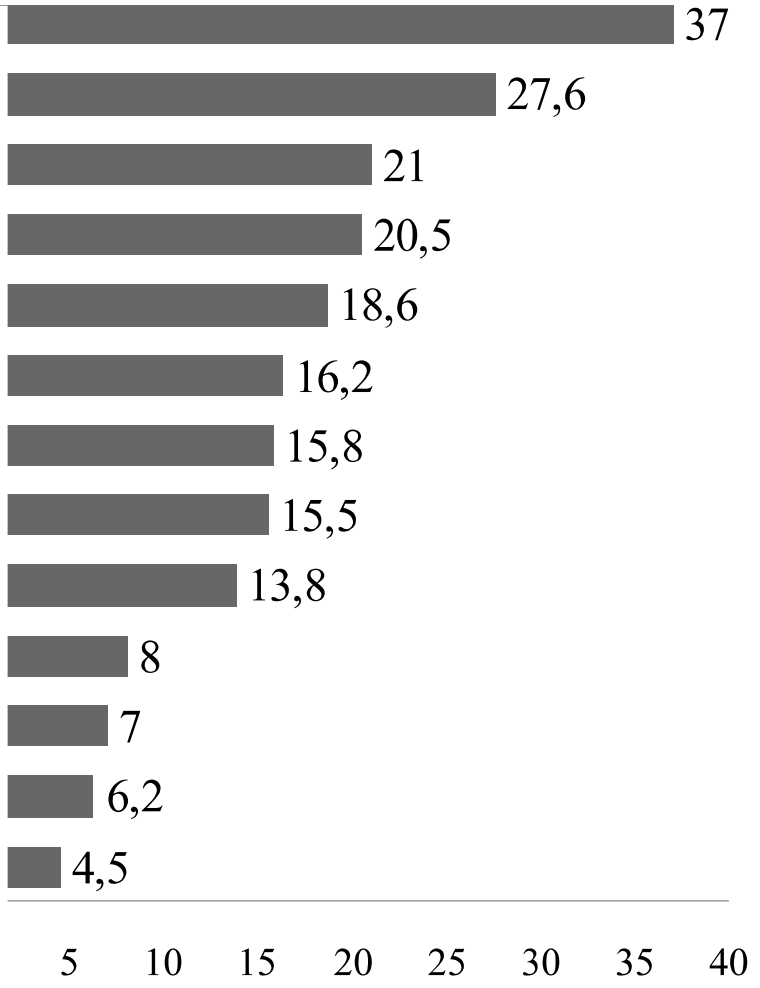

Рис. 1. Кількість вступників із балами менше 150, рекомендованих до зарахування до медичних вишів у 2017 році.

Варто наголосити, що в Рейтингу закладів вищої освіти України за Індексом прозорості антикорупційної політики (ІПАП-2017) [11], набравши 18 балів і здобувши 62,07 \% рівня прозорості (РП, максимальний РП був оцінений у 83,62 \%), академія посіла 11 місце серед 165 вищих навчальних закладів і фактично 4 місце серед ВМ(Ф)НЗ, поступившись трьом 3ВО, які перебувають у підпорядкуванні МО3: Тернопільському державному медичному університету імені І. Я. Горбачевського - 20,5 б. і 2 місце в загальному рейтингу (70,69\% РП), Одеському національному медичному університету - 18,5 б. і 7 місце в загальному рейтингу (63,79 \% РП) та Національному фармацевтичному університету - 18,25 б. і 10 місце в загальному рейтингу (62,93 \% РП).

3 метою забезпечення якості навчання й оприлюднення його результатів запроваджено інформаційну систему обліку і моніторингу відвідування занять та успішності студентів - Електронний журнал успішності, який відповідає прийнятій в академії політиці прозорості, забезпечує відкритий доступ до оцінки навчальних досягнень студентів і реєстрів науково-педагогічних працівників.

Важливим кроком на шляху до прозорості й об'єктивності оцінювання навчальних досягнень студентів стало запровадження в академії відпрацювань пропущених занять в електронних залах. Натепер відпрацювання проводять у трьох залах і на 108 комп’ютерах. Для організації електронних відпрацювань викладачі створили потужну тестову базу з усіх навчальних дисциплін, вивчення яких передбачене навчальними планами. Станом на 1 січня 2018 року в базі налічувалося 1 млн 295 тис. 314 тестів закритої форми. Згідно з рішенням ректорату від 13 березня 2017 року (протокол № 19), організовано її щомісячне поновлення. Варто наголосити на тому, що таке управлінське рішення сприяє не лише суттєвому зменшенню кількості пропущених занять (рис. 2), але й розвитку та вдосконаленню методичної компетентності викладачів.

Усвідомлюючи те, що за умов компетентнісної освітньої парадигми одним із першочергових завдань $є$ підготовка і реалізація освітніх програм нового покоління, які повинні як відповідати сучасним досягненням у відповідній галузі світової та вітчизняної медичної (фармацевтичної) науки, так і враховувати передовий досвід викладання тих чи інших дисциплін у 3ВО [8], у 2017 році 11 опорними кафедрами та провідними фахівцями академії укладено 16 програм (типових, примірних), затверджених МОЗ України. 


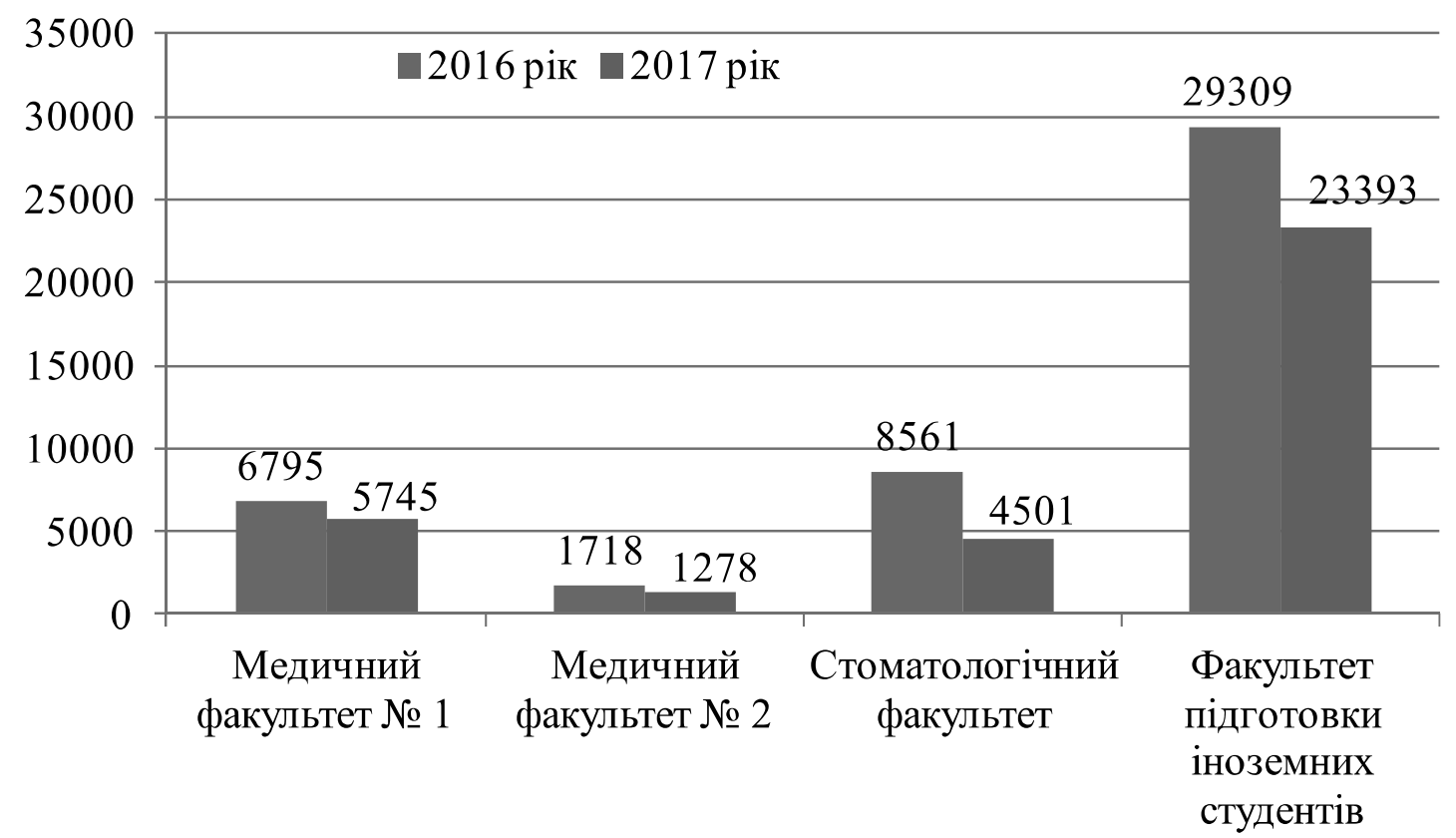

Рис. 2. Динаміка зменшення кількості пропущених занять (вересень - грудень 2016 р./вересень - грудень 2017 року).

Беручи до уваги положення чинного законодавства у сфері вищої освіти та на виконання Ліцензійних умов, в академії традиційно приділяють пильну увагу такому напрямку навчально-методичного забезпечення освітнього процесу, як підготовка і видання якісної навчальної та навчально-методичної літератури. Керуючись ст. 32 "Принципи діяльності, основні права та обов'язки вищого навчального закладу” розділу VI Закону України “Про вищу освіту” [2], наказами МОН України від 09.09.2014 року № 1006, МО3 України від 28.08.2017 року № 972 та листом ДУ “Центральний методичний кабінет з вищої медичної освіти” від 01.09.2017 року № 23-01-9/370 і 3 метою забезпечення належного контролю якості навчально-методичної літератури та проведення її фахової експертизи і надання навчальним та навчально-методичним виданням грифа вченої ради ВДНЗУ “УМСА” або Центральної методичної комісії ВДНЗУ “УМСА”, в академії створено Науковометодичну комісію з видавничої діяльності, яку очолює перший проректор.

Загалом у 2017 році науково-педагогічні працівники академії стали авторами і співавторами 9 підручників, 8 з яких - національні. Протягом цього періоду вийшло друком 166 навчальних і навчально-методичних посібників, з яких 49 з грифами МОН України, МОЗ України, ДУ “ЦМК з ВМО МОЗ України”, 117 - з грифами вченої ради
ВДНЗУ “УМСА” і вчених рад інших ВМ(Ф)НЗ, а також створено 17 монографій.

Підтвердженням професіоналізму і фахової компетентності науковців академії слугують високі відзнаки у вигляді премій. Так, Указом Президента України від 7 квітня 2017 року № 101/2017 “Про присудження Державних премій України в галузі науки і техніки 2016 року” колектив авторів підручника “Фармакологія” (Вінниця : Нова книга, 2011. 432 с.), серед яких і 4 співробітники академії В. М. Бобирьов, М. М. Рябушко, Т. А. Петрова, Г. Ю. Островська, став лауреатом вказаної премії. Другою премією та дипломом журі конкурсу Академії наук вищої освіти України у 2017 році нагороджені проф. Т. О. Крючко і доц. Т. В. Кушнерева за підручник для англомовних студентів “Pediatrics” (“Педіатрія").

Принагідно зазначимо, що книгозабезпеченість навчальних дисциплін відповідає ліцензійним вимогам: з гуманітарних і соціально-економічних дисциплін цей показник становить $97 \%$, із природничо-наукових - 98,5 \%, із професійної підготовки $-98,4 \%$.

Слід наголосити на тому, що відповідно до законів України “ Про вищу освіту” [2], “Про авторське право та суміжні права” [1], “Про наукову і науковотехнічну діяльність” [3] та з метою дотримання академічної доброчесності всі текстові документи, навчальні й навчально-методичні видання зокрема, 
створені педагогічними і науково-педагогічними працівниками академії, проходять перевірку на наявність плагіату. В разі отримання негативної оцінки роботи повертають авторам на доопрацювання.

Як один із дієвих кроків у напрямку дотримання академічної доброчесності та неправомірного використання чужих творів, а також з метою оприлюднення праць співробітників ВДНЗУ “УМСА” наказом ректора академії від 13 вересня 2017 року № 309 створено інституційний репозитарій. Натепер у репозитарій завантажено 149 авторефератів і дисертацій, 530 продуктів інтелектуальної власності, 6708 наукових праць, навчальних матеріалів і презентацій, а також методичних видань.

У 2017 році освітній процес в академії забезпечували 92 доктори наук і 406 кандидатів наук, що становить 78,9 \% від загальної кількості науковопедагогічних працівників. Натепер в академії налічується 24 кафедри, штат яких на 95-100 \% укомплектований науково-педагогічними працівниками, які мають науковий ступінь доктора або кандидата наук.

Керуючись ст. 60 “Післядипломна освіта, підвищення кваліфікації та стажування педагогічних i науково-педагогічних працівників” розділу X “Учасники освітнього процесу” Закону України від 01.07.2014 року № 556-VII “Про вищу освіту” [2] і Положенням про підвищення кваліфікації та стажування педагогічних і науково-педагогічних працівників вищих навчальних закладів, затвердженим наказом Міністерства освіти і науки, молоді та спорту України від 24.01.2013 року № 48, та будучи свідомими того, що якість підготовки майбутніх фахівців у галузі охорони здоров’я i, в кінцевому результаті, якість надання медичних послуг значною мірою залежать від такої ключової фігури освітнього процесу, як викладач вищої медичної школи, який повинен бути не лише конкурентоспроможним професіоналом найвищого гатунку, але й майстерним педагогом [4], науково-педагогічні працівники академії здійснюють довгострокове підвищення кваліфікації (з обсягом навчальної програми три кредити ECTS) не рідше одного разу на п’ять років. У 2017 календарному році підвищили кваліфікацію 26,6 \% штатних викладачів - 151 особа.

Протягом 2017 року значну увагу приділяли таким короткостроковим формам підвищення кваліфікації, як участь у науково-практичних, навчально-методичних, науково-методичних конференціях різного рівня. Упродовж зазначеного періоду науково-педагогічні працівники академії взяли участь у 218 конференціях. Безпосередньо на базі академії було проведено 10 всеукраїнських і міжнародних конференцій, які внесено до реєстру МОЗ і НАМН України.

Варто підкреслити, що принципова і водночас конструктивна позиція керівництва академії щодо покращення якості кадрового забезпечення освітнього процесу дає позитивні результати, на користь чого свідчить позитивна динаміка зростання протягом останніх п’яти років такого показника, як “оцінка якості науково-педагогічного потенціалу”, що відображено в незалежних рейтингах [9].

Упродовж 2017 року в рамках запровадження безвізового режиму та реалізації програм академічної мобільності 31 викладач академії взяв участь у закордонних конференціях і стажуваннях у провідних освітньо-наукових установах та медичних закладах Естонії, Литви, Словаччини, Франції, Швеції, Норвегії, Польщі, Австрії, Туреччини, Італії, Ірландії, Китаю, США. Така форма підвищення кваліфікації дала змогу вивчити кращий європейський лікувальний, адміністративний і педагогічний досвід, взяти участь у сумісній розробці інноваційних методів навчання, обмінятися науковими здобутками та ідеями, ознайомитися з новітніми досягненнями європейської та світової медичної і медико-педагогічної науки, педагогічними технологіями, а також перспективами їх подальшого розвитку.

У 2017 році між ВДНЗУ “УМСА” та Університетом Поля Сабатьє, м. Тулуза, Франція (Université Paul Sabatier) і Університетом Аристотеля, м. Салоніки, Греція (Aristotle University) було укладено двосторонні угоди про співпрацю в рамках міжнародної програми академічного обміну Erasmus+. Згідно з договорами про академічну мобільність у 2017 році в університетах Поля Сабатьє і Аристотеля пройшли стажування та навчання 3 представники академії.

Для викладачів (асистентів), науково-педагогічний стаж яких менший п’яти років, протягом вказаного періоду в академії було організовано семінари з педагогічної майстерності (33 особи), на яких розглядали актуальні питання педагогіки і психології вищої школи. Також організовували круглі столи і семінари, тренінги, майстер-класи. Заслуговує на увагу неформальне навчання у ви- 
гляді так званого “інституту наставництва” - прикріплення молодих викладачів до досвідчених доцентів і професорів, які консультують початківців з питань методики викладання певної дисципліни, ведення i/або створення методичної документації, ознайомлюють молодь із педагогічними технологіями і долучають її до створення різноманітних засобів навчання.

Пильну увагу в академії приділяють такій важливій формі підвищення кваліфікації, як написання і захист наукових кваліфікаційних праць. Упродовж 2017 року один науково-педагогічний працівник академії здобув науковий ступінь доктора наук і 16 - PhD. Стипендію Кабінету Міністрів України для молодих учених отримували 2 викладачі академії.

Висновки. Проведений самоаналіз організаційноправового, кадрового і навчально-методичного забезпечення процесу підготовки фахівців галузі

\section{Список літератури}

1. Про авторське право і суміжні права : Закон України від 23.12.1993 року № 3792-XII [Електронний ресурс]. - Режим доступу : http://zakon0.rada.gov.ua/laws/ show/3792-12.

2. Про вищу освіту : Закон України від 01.07.2014 року № 15566-VII (із змінами) [Електронний ресурс]. - Режим доступу : http://zakon.rada.gov/ua/go/1556-18.

3. Про наукову і науково-технічну діяльність : Закон України (із змінами, внесеними згідно із Законами № 922-VIII від 25.12.2015, ВВР, 2016, № 9, ст. 89, № 1774-VIII від 06.12.2016, ВВР, 2017, № 2, ст. 25) [Електронний ресурс]. - Режим доступу : http://zakon0. rada.gov.ua/laws/show/848-19.

4. Бєляєва О. М. Розвиток педагогічної майстерності викладачів вищих медичних навчальних закладів: проблеми і шляхи розв'язання / О. М. Бєляєва // Pedagogy and Psychology. - 2018. - VI (63), Issue 153. - P. 15-19.

5. Біла книга національної освіти України / [Т. Ф. Алексєєнко, В. М. Аніщенко, Г. О. Балл та ін.] ; за заг. ред. В. Г. Кременя. - К. : ТОВ “Інформаційні системи”, 2010. - 342 с.

6. Авраменко Т. П. Кадрова політика реформування сфери охорони здоров'я : аналітична доповідь / Т. П. Авраменко. - К. : НІСД, 2012. - 35 с.

7. Медична освіта в Україні: погляд у майбутнє // Аптека. - 2017. - № 12 (1083) (З квіт. )[Електронний ресурс]. Режим доступу : http://www.apteka.ua/article/405874.

8. Мельник I. В. Навчально-методичне забезпечення підготовки студентів у вищих навчальних закладах МO3 знань 22 “Охорона здоров'я” у ВДНЗУ “УМСА” за 2017 рік засвідчив, що це забезпечення відповідає чинному законодавству України, свідчить про ефективний менеджмент керівництва та ефективність управлінських рішень, спрямованих на забезпечення конкурентоспроможності академії. Водночас існує потреба в покращенні таких напрямів роботи, як: збільшення кількості науковопедагогічних працівників із науковим ступенем; збільшення кількості підручників і посібників, виданих у спеціалізованих видавництвах; ширше залучення провідних науковців академії до роботи над національними підручниками; продовження суворого контролю за якістю методичних розробок, особливо для студентів англомовної форми навчання; активізація роботи щодо академічної мобільності; збільшення кількості конференцій, внесених до реєстру МОЗ і НАМН України, що мають проходити на базі академії.

України: стан та першочергові завдання / I. В. Мельник, М. О. Поліщук // Медична освіта. - 2017. - № 3. C. 13-21.

9. Порівняльний аналіз показників якості освітньої діяльності ВДНЗУ “УМСА” за 2013-2017 рр. / В. М. Ждан, В. М. Дворник, В. М. Бобирьов [та ін.] // Актуальні питання контролю якості освіти у вищих навчальних закладах : матеріали наук.-практ. конф. з міжнар. участю (Полтава, 22 берез. 2018 р.). - Полтава : Ред.-вид. відділ ВДНЗУ “УМСА”, 2018. - С. 3-7.

10. Про затвердження Ліцензійних умов провадження освітньої діяльності закладів освіти : Постанова Кабінету Міністрів України від 30.12.2015 року № 1187 [Електронний ресурс]. - Режим доступу : http://zakon3.rada. gov.ua/laws/show/1187-2015-\%D0\%BF.

11. Рейтинг закладів вищої освіти України за Індексом прозорості антикорупційної політики (ІПАП2017) [Електронний ресурс]. - Режим доступу : http:// europrojects.org.ua/tiap-2017-raiting/.

12. Стратегии развития кадров здравоохранения в Европейском регионе. Европейский региональный комитет. Пятьдесят седьмая сессия (Белград, Сербия, 17-20 сент. 2007 г.) [Электронный ресурс]. - Режим доступа : http://www.euro.who.int/_data/assets/pdf_ file/0005/74543/.

13. Шляхи формування системи вищої медичної освіти України в сучасних умовах / О. В. Лінчевський, В. М. Черненко, Ю. С. П’ятницький, І. Є. Булах // Медична освіта. - 2017. - № 3. - С. 6-9. 


\section{References}

1. Zakon Ukrainy "Pro avtorske pravo i sumizhni prava" vid 23.12.1993 № 3792-XII [Law of Ukraine on copyright and related rights of December 23 1993, No. 3792-XII]. Retrieved from: http://zakon0.rada.gov.ua/laws/show/379212 [in Ukrainian]

2. Zakon Ukrainy "Pro vyshchu osvitu" vid 01.07.2014 r. № 15566-VII (iz zminamy) [Law of Ukraine on higher education" (as amended) of July 01 2014, No. 15566-VII]. Retrieved from: http://zakon.rada.gov/ua/go/1556-18 [in Ukrainian]

3. Zakon Ukrainy "Pro naukovu i naukovo-tekhnichnu diialnist” (iz zminamy, vnesenymy zhidno iz Zakonamy № 922-VIII vid 25.12.2015, BBP, 2016, № 9, st. 89, № 1774-VIII vid 06.12.2016, BBP, 2017, № 2, st. 25) [Law of Ukraine on scientific practices and scientific and technological practices (as amended by the laws]. Retrieved from: http://zakon0.rada.gov.ua/laws/show/84819 [in Ukrainian].

4. Bieliaieva, O. M. (2018) Rozvytok pedahohichnoi maisternosti vykladachiv vyshchykh medychnykh navchalnykh zakladiv: problemy i shliakhy rozviazannia [Development of pedagogical excellence of medical school teaching staff: problems and ways of solution]. Pedahohika i Psykholohiia - Pedagogy and Psychology, VI (63), 153, 15-19 [in Ukrainian].

5. Aleksyenko, T.F., Anishchenko, V.M., \& Ball, H.O. (2010). Bila knyha natsionalnoi osvity Ukrainy [White Book of National Education of Ukraine]. Kremenia, V.H. (Ed.). Kyiv: TOV "Informatsiini systemy” [in Ukrainian].

6. Avramenko, T.P. (2012) Kadrova polityka reformuvannia sfery okhorony zdorovia: analitychna dopovid [Personnel policy of health care reforming: white paper]. Kyiv NISD [in Ukrainian].

7. Medychna osvita v Ukraini: pohliad u maibutnie [Medical education in Ukraine: projection into the future]. AptekaPharmacy, 12 (1083). - Retrieved from: http://www.apteka. ua/article/405874 [in Ukrainian].

8. Melnyk, I.V., \& Polishchuk, M.O. (2017). Navchalno-metodychne zabezpechennia pidhotovky studentiv u vyshchykh navchalnykh zakladakh MOZ Ukrainy: stan ta pershocherhovi zavdannia [Methodological support of students training in higher educational establishments of the
Ministry of Health of Ukraine]. Medychna osvita-Medical Education, 3, 13-21.

9. Zhdan, V.M., Dvornyk, V.M., \& Bobyrov, V.M. (2018). Porivnialnyi analiz pokaznykiv yakosti osvitnoi diialnosti VDNZU “UMSA” za 2013-2017 rr. [A comparative analysis of the quality indicators of educational activities of higher educational institutions of Ukraine]. Aktualni pytannia kontroliu yakosti osvity u vyshchykh navchalnykh zakladakhTopical Issues of Education and Higher Educational Institutions Quality Control. Mizhnarodna naukovo-praktychna konferentsiia - International Scientific and Practical Conference. Poltava: Red.-vyd. viddil VDNZU “UMSA” [in Ukrainian].

10. Pro zatverdzhennia litsenziinykh umov provadzhennia osvitnoi diialnosti zakladiv osvity [On approval of licensing conditions for the educational activities of educational institutions]. Postanova Kabinetu Ministriv Ukrainy vid 30.12.2015 roku № 1187. Order of the Cabinet of Ministers from December 30, 2015 - Retrieved from: http://zakon3. rada.gov.ua/laws/show/1187-2015-\%D0\%BF [in Ukrainian].

11. Reitynh zakladiv vyshchoi osvity Ukrainy za indeksom prozorosti antykoruptsiinoi polityky (IPAP-2017) [Rating of higher education institution of Ukraine according to the index of transparency of anticorruption policy]. - Retrieved from: http://europrojects.org.ua/tiap-2017-raiting/ [in Ukrainian].

12. Stratehii razvitiya kadrov zdravookhraneniya $v$ Yevropeyskom regione [Development strategies of healthcare staff in European region]. Yevropeiskiy regionalnyi komitet. Pyatdesyat sedmaya sessiya - European Regional Committee. Fifty seventh session. Belgrad, Serbiia, 17-20 sentiabria 2007 g.). - Retrived from: http://www.euro.who.int/_data/ assets/pdf_file/0005/74543/

13. Linchevskyi, O.V., Chernenko, V.M., Piatnytskyi, Yu.S., \& Bulakh, I.Ye. (2017). Shliakhy formuvannia systemy vyshchoi medychnoi osvity Ukrainy v suchasnykh umovakh [Ways of forming the system of higher medical education of Ukraine in modern conditions]. Medychna osvita Medical Education, 3, 6-9. 